\title{
Mapping Offshore Winds Around Iceland Using Satellite Synthetic Aperture Radar and Mesoscale Model Simulations
}

\author{
Hasager, Charlotte Bay; Badger, Merete; Nawri, Nikolai; Rugaard Furevik, Birgitte; Petersen, Guðrún \\ Nína ; Björnsson, Halldór ; Clausen, Niels-Erik
}

Published in:

I E E E Journal of Selected Topics in Applied Earth Observations and Remote Sensing

Link to article, DOI:

10.1109/JSTARS.2015.2443981

Publication date:

2015

Document Version

Publisher's PDF, also known as Version of record

Link back to DTU Orbit

Citation (APA):

Hasager, C. B., Badger, M., Nawri, N., Rugaard Furevik, B., Petersen, G. N., Björnsson, H., \& Clausen, N-E. (2015). Mapping Offshore Winds Around Iceland Using Satellite Synthetic Aperture Radar and Mesoscale Model Simulations. I E E E Journal of Selected Topics in Applied Earth Observations and Remote Sensing, 8(12), 5541-5552. https://doi.org/10.1109/JSTARS.2015.2443981

\section{General rights}

Copyright and moral rights for the publications made accessible in the public portal are retained by the authors and/or other copyright owners and it is a condition of accessing publications that users recognise and abide by the legal requirements associated with these rights.

- Users may download and print one copy of any publication from the public portal for the purpose of private study or research.

- You may not further distribute the material or use it for any profit-making activity or commercial gain

- You may freely distribute the URL identifying the publication in the public portal 


\title{
Mapping Offshore Winds Around Iceland Using Satellite Synthetic Aperture Radar and Mesoscale Model Simulations
}

\author{
Charlotte Bay Hasager, Merete Badger, Nikolai Nawri, Birgitte Rugaard Furevik, Guơrún Nína Petersen, \\ Halldór Björnsson, and Niels-Erik Clausen
}

\begin{abstract}
The offshore wind climate in Iceland is examined based on satellite synthetic aperture radar (SAR), coastal meteorological station measurements, and results from two atmospheric model data sets, HARMONIE and NORA10. The offshore winds in Iceland are highly influenced by the rugged coastline. Lee effects, gap flow, coastal barrier jets, and atmospheric gravity waves are not only observed in SAR, but are also modeled well from HARMONIE. Offshore meteorological observations are not available, but wind speed and wind direction measurements from coastal meteorological masts are found to compare well to nearby offshore locations observed by SAR. More than 2500 SAR scenes from the Envisat ASAR wide swath mode are used for wind energy resource estimation. The wind energy potential observed from satellite SAR shows high values above $1000 \mathrm{Wm}^{-2}$ in coastal regions in the south, east, and west, with lower values in the north. The most promising region for wind energy production is the southwestern coastal region.
\end{abstract}

Index Terms-Offshore resource, polarization ratio (PR), synthetic aperture radar (SAR), wind energy, wind speed.

\section{INTRODUCTION}

D UE to the location of Iceland both close to the North Atlantic storm tracks [1] and just east of Greenland, the wind climate of Iceland is both varied and at times extremely harsh. As wind turbines in recent decades have become more robust for applications in extreme climates, the interest of wind energy utilization in Iceland has increased. Mapping the wind

\footnotetext{
Manuscript received February 16, 2015; revised May 18, 2015; accepted June 05, 2015. Date of publication July 09, 2015; date of current version January 25, 2016. This work was part of the project "Improved Forecast of Wind, Waves and Icing" (ICEWIND), www.icewind.dtu.dk, supported by the Nordic Top-level Research Initiative (Toppforskningsinitiativet; TFI), including national and private organizations. Satellite data from the European Space Agency, ESA Grant EO-14048 and Grant EO-6773, and the JHU APL software and support from Dr. Frank M. Monaldo. Sea ice mask: National Ice Center. 2008, updated daily. IMS daily Northern Hemisphere snow and ice analysis at 4- and 24-km resolution. Boulder, CO: National Snow and Ice Data Center. http://dx.doi.org/10.7265/N52R3PMC.

C. B. Hasager, M. Badger, and N.-E. Clausen are with the DTU Wind Energy, Technical University of Denmark, 4000 Roskilde, Denmark (e-mail: cbha@dtu.dk; mebc@dtu.dk; necl@dtu.dk).

N. Nawri, G. N. Petersen, and H. Björnsson are with the Icelandic Meteorological Office, 108 Reykjavik, Iceland (e-mail: nikolai@vedur.is; gnp@vedur.is; halldor@vedur.is).

B. R. Furevik is with the Norwegian Meteorological Institute, 5007 Bergen, Norway, and also with the Geophysical Institute, University of Bergen, Bergen 5007, Norway (e-mail: birgitte.furevik@ met.no).

Color versions of one or more of the figures in this paper are available online at http://ieeexplore.ieee.org.

Digital Object Identifier 10.1109/JSTARS.2015.2443981
}

resource is a vital part of understanding the feasibility. The wind conditions over Iceland have been studied for several years, using numerical models and in situ observations, in particular the distortion of the near-surface wind field by orography [2], [3], as well as a severe storm in northeast of Iceland [4]. Recently, an onshore wind atlas for Iceland was completed [5]. It confirms that the wind conditions on land are promising for wind energy production, although they are not yet exploited on a significant scale. However, there is an increased interest, and the largest power company in Iceland, Landsvirkjun, erected two wind turbines in 2013, initially for research purposes. An offshore wind resource map for Iceland would give useful additional information, if this clean energy resource is to be exploited at a later stage. Here, we present the first offshore wind resource map for the seas surrounding Iceland. The basis for most offshore wind resource maps is atmospheric modeling, the results of which are compared to offshore meteorological mast observations [6], [7]. However, offshore meteorological observations in Iceland are not available. Instead, in this study, satellite remote-sensing data are used for the estimation of wind energy resources, which has been identified as one of the nine societal benefit areas of the Global Earth Observations Systems of Systems (GEOSS) program.

The available satellite remote-sensing observations leading to surface ocean wind vectors are from microwave remote sensing. Previously, wind resource estimation has been done at a spatial resolution around $25 \times 25 \mathrm{~km}$ in the Mediterranean Sea [8] and the Northern European Seas [9], [10], using data archives with ocean surface vector wind data from QuikSCAT. For Iceland, the most relevant areas with regard to offshore wind energy are expected to be near-coastal, i.e., less than $25 \mathrm{~km}$ from the coast. The coastline of Iceland is very complex in places and a spatial resolution of $25 \times 25 \mathrm{~km}$ does not provide sufficient near-coastal coverage. Satellite synthetic aperture radar (SAR) provides microwave data useful for ocean wind mapping at around $1 \times 1 \mathrm{~km}$ [11]-[13], which allows near-coastal wind mapping. Significant gradients in coastal winds have been observed from SAR at less complex coastlines [14], [15]. This satellite data source has therefore potential to be able to resolve winds near the coast of Iceland and is thus chosen for the study. We use SAR scenes from the European Space Agency (ESA), obtained by the Envisat satellite, which carried the advanced SAR (ASAR) instrument.

Satellite SAR was used for wind resource estimation based on a few samples from RadarSat-1 data in Canadian waters 
[16], [17], whereas in Japanese waters [18] and in Chinese waters [19], [20] Envisat ASAR was used. In the Northern European Seas, many Envisat ASAR samples were used for wind resource estimation [21]. Wind resource mapping is usually based on hourly values from one or more years, i.e., around 8760 observations or more. Fewer values may be used, but with increasing statistical uncertainty [22], [23].

The objective of the study is to investigate the quality of offshore winds derived from SAR in the coastal regions of Iceland.

SAR winds are compared with data from several coastal meteorological stations, as well as two atmospheric models: HARMONIE [24], [25] operated by the Icelandic Meteorological Office (IMO) and high-resolution limited area model (HIRLAM) applied in the Norwegian Reanalysis of wind and waves (NORA10) [26], [27]. The numerical models provide data on regular horizontal grids and at regular time intervals, whereas the satellite data are irregular in both space and time. However, due to the higher spatial resolution, more details in the offshore wind field can be expected from satellite observations than from modeling.

Two tests of SAR data quality will be performed.

1) Selected cases of atmospheric flow observed by SAR are examined and compared to HARMONIE model simulations, with a focus on specific meteorological phenomena in which the coastal influences on offshore winds are dominant.

2) In order to assess the overall accuracy of the applied SAR wind retrieval, a number of colocated samples of SAR and NORA10 model data are compared. Additionally, a comparison is made between coastal meteorological observations and nearby SAR offshore data.

The first test focuses on the spatial pattern of wind phenomena observed by SAR and simulated by HARMONIE, for distinct large-scale atmospheric weather patterns that are typical around Iceland. Earlier studies have compared coastal SAR winds and atmospheric model results in regions with complex coastlines near Alaska [28], [29], Svalbard [30], [31], Greenland [32], and the Philippines [33].

The second test is aimed primarily on the local agreement over time between SAR and model data. Studies from the Baltic Sea comparing SAR-derived winds to offshore meteorological wind observations from masts, dedicated specifically to wind resource assessments, show a root-mean-square error (RMSE) around $1.2 \mathrm{~ms}^{-1}$ and a bias around $-0.25 \mathrm{~ms}^{-1}$ [34]. In Iceland, SAR wind maps over the open ocean are compared to NORA10 model results, as this model has been shown to successfully compare to ocean wind observations in the Norwegian Sea and the North Sea [27]. Also, a high number of collocated samples are available. More specifically, the choice of polarization ratio (PR) is determined from this analysis. The wind direction input used to drive the wind speed retrieval is from the U.S. Navy Operational Global Atmospheric Prediction System (NOGAPS) [35]. The accuracy of NOGAPS wind direction near Iceland is expected to be comparable to results from the Baltic Sea, where wind directions observed at ten offshore meteorological masts show an RMSE of $6.3^{\circ}$, a bias of $7.8^{\circ}$, and a mean squared correlation coefficient $\mathrm{R}^{2}$ of 0.95 [26].

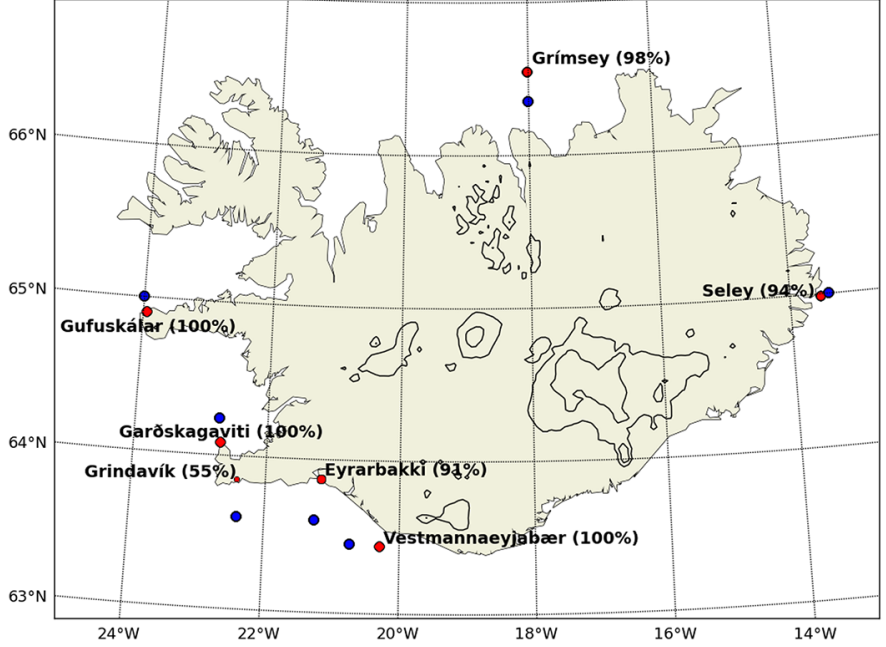

Fig. 1. Map of Iceland showing the locations (red dots) and names of weather stations from which data are used in this study. The availability of station data in percent of the dates included in the nearest SAR time series is shown in parentheses. The locations of points from which SAR time series were retrieved are indicated by blue dots.

TABLE I

Overview of THE COASTAL STATIONS From Which DATA ARE Used in this Study: Name, Location, Height Above SeA LEVEL, AND START OF OPERATION YEAR

\begin{tabular}{|l|l|l|l|}
\hline Name & Location & Height $(\mathrm{m})$ & Year \\
\hline Grindavík & $63.84 \mathrm{~N}, 22.417 \mathrm{~W}$ & 9.3 & 2008 \\
\hline Garðskagaviti & $64.08 \mathrm{~N}, 22.69 \mathrm{~W} 3$ & 4.0 & 1995 \\
\hline Gufuskálar & $64.90 \mathrm{~N}, 23.93 \mathrm{~W}$ & 7.0 & 1994 \\
\hline Grímsey & $66.54 \mathrm{~N}, 18.02 \mathrm{~W}$ & 19.0 & 2005 \\
\hline Seley & $64.98 \mathrm{~N}, 13.52 \mathrm{~W}$ & 18.0 & 1996 \\
\hline Vestmannaeyjabær & $63.44 \mathrm{~N}, 20.28 \mathrm{~W}$ & 40.4 & 2002 \\
\hline Eyrarbakki & $63.87,21.16 \mathrm{~W}$ & 3.0 & 2005 \\
\hline
\end{tabular}

\section{STUdy AREA AND DATA}

The study area is located between $62^{\circ}-68^{\circ} \mathrm{N}$ and $11^{\circ}-27^{\circ} \mathrm{W}$. It covers Iceland and the surrounding seas. The wind observations are retrieved from seven coastal automatic weather stations; see Fig. 1 for their locations. Table I contains further information on the stations. Wind speed and direction are measured hourly at $10 \mathrm{~m}$ above ground level (AGL). The time period considered here ranges from 2005 to 2012. The availability of station data in percent of the dates included in the nearest SAR time series is shown in parentheses in Fig. 1. Usually, the data availability is very good $(>90 \%)$.

\section{A. SAR Data}

In total, 2581 Envisat ASAR scenes are used in the study. The number of SAR scenes per year can be found in Table II, and the number of scenes per calendar month in Table III. The number of samples per month is around $200( \pm 50)$. In 
TABLE II

Number of SAR Scenes Per Year in the Area of Interest During the Time Period January 2005-January 2012

\begin{tabular}{|l|l|l|l|l|l|l|l|l|}
\hline Year & 2005 & 2006 & 2007 & 2008 & 2009 & 2010 & 2011 & 2012 \\
\hline No. of scenes & 206 & 202 & 256 & 290 & 446 & 561 & 609 & 11 \\
\hline
\end{tabular}

Note that after January 2012, the Envisat mission was terminated.

TABLE III

Number of SAR Scenes Per Calendar Month in the Area of Interest During the Time Period January 2005-January 2012

\begin{tabular}{|l|l|l|l|l|l|l|l|l|l|l|l|l|}
\hline Month & Jan & Feb & March & April & May & June & July & Aug & Sept & Oct & Nov & Dec \\
\hline No. of scenes & 207 & 159 & 185 & 198 & 228 & 213 & 231 & 256 & 209 & 236 & 227 & 232 \\
\hline
\end{tabular}

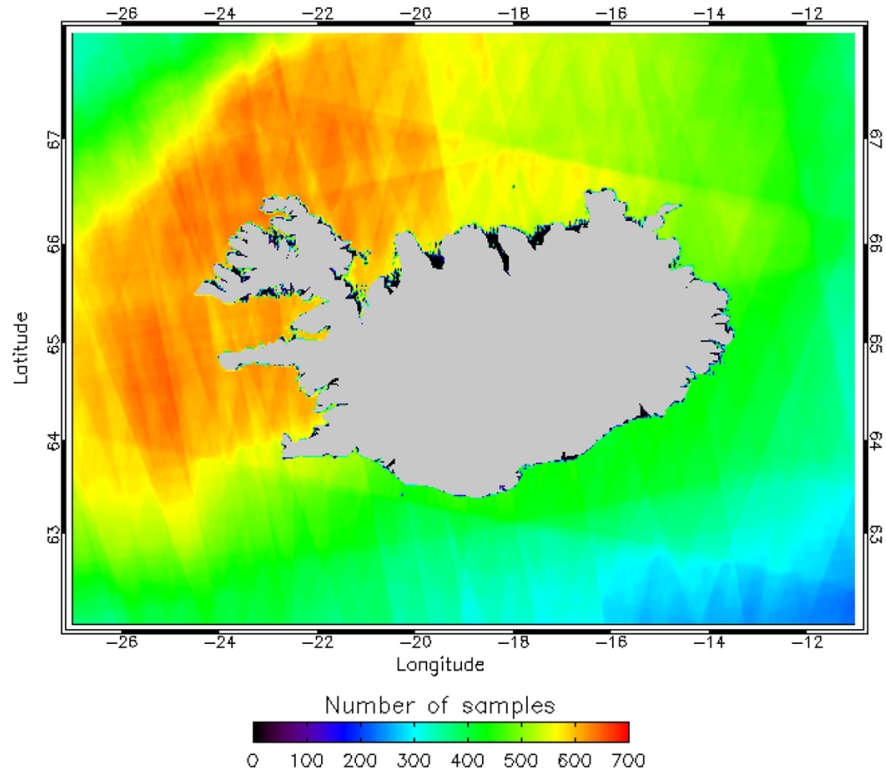

Fig. 2. Number of overlapping Envisat ASAR satellite wind maps used for this study.

descending mode, 1339 scenes are collected within the time period of 19:53-23:52 UTC; in ascending mode, 1242 scenes between 10:58 and 13:13 UTC. SAR scenes at high latitudes are typically acquired for sea ice monitoring [36]. Horizontal polarization in transmit and receive (HH) is most suitable for this purpose, and the number of scenes in $\mathrm{HH}$ is thus high compared to the number of scenes with vertical polarization (VV). This data set holds a total of $2399 \mathrm{HH}$ scenes and only $182 \mathrm{VV}$ scenes. Fig. 2 shows the number of overlapping SAR scenes used in the study. There are more than 650 overlapping samples to the north west of Iceland, decreasing to 250 in the southeast corner of the domain. The near-shore areas of Iceland are covered by more than 400 samples.

The SAR images are calibrated and resampled to a grid cell size of $0.5 \mathrm{~km}$ in both horizontal directions to reduce random noise. To retrieve wind speed, it is necessary to select and apply a geophysical model function (GMF) and introduce wind direction and incidence angle to this function. The wind speed is retrieved using the GMF CMOD5.N [37] for the level at $10 \mathrm{~m}$ above the sea surface. It is the equivalent neutral wind speed.
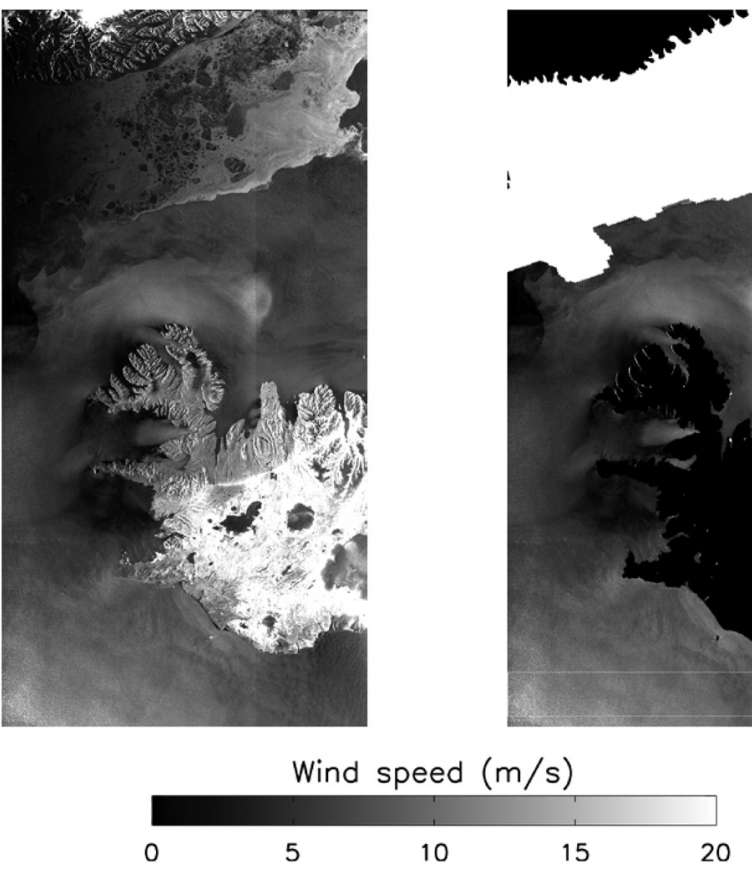

Fig. 3. Wind speed map retrieved from Envisat ASAR WSM on May 30, 2010 at 22:49 UTC. Left: A large area along the coast of Greenland is covered by sea ice. Right: Masking has been applied to the wind speed map to remove the land- (black) and ice-covered areas (white). The two white lines indicate the transect used in Fig. 4.

The wind direction input used to drive the wind speed retrieval is from the NOGAPS [35]. The model simulations are given at $1^{\circ}$ spatial resolution and six-hourly values. As the model has much lower spatial resolution than SAR data, the NOGAPS wind directions are interpolated spatially to each image pixel in the SAR wind retrieval [38].

Sea ice occurs in Icelandic waters during winter, mainly as frazil ice in the northern fjords. Land- and ice-covered areas are not suitable for SAR wind retrieval. A mask is therefore applied to eliminate these areas. Sea ice information is obtained from the IMS Daily Northern Hemisphere Snow and Ice Analysis at 4-km Resolution by the U.S. National Ice Center (http://nsidc.org/data/docs/noaa/g02156_ims_snow_ ice_analysis/). Fig. 3 shows an example of wind speed map extending from the south of Greenland to the seas south of the 


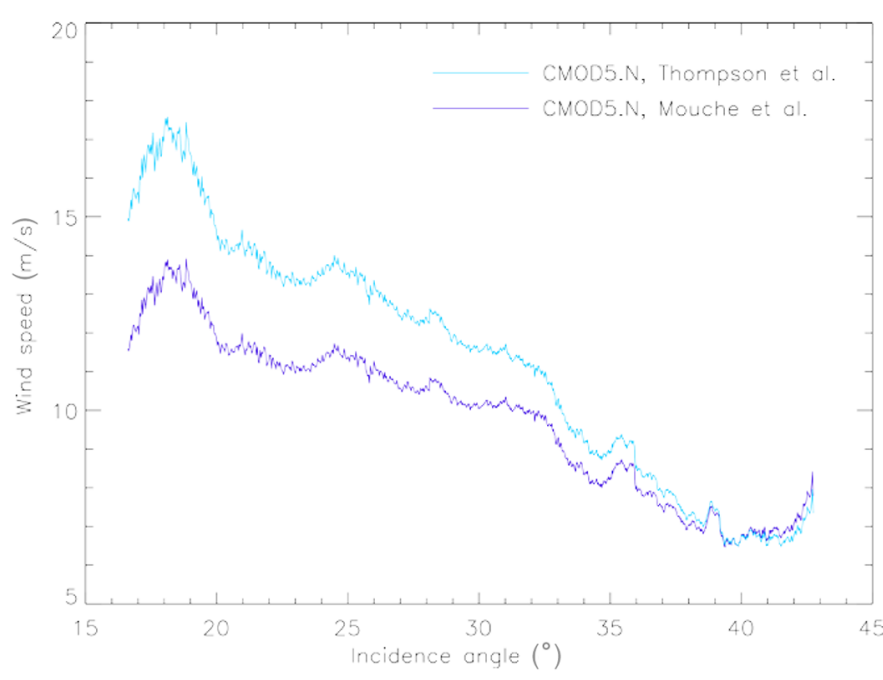

Fig. 4. Mean wind speed across the swath of the Envisat ASAR WSM scene from May 30, 2010 at 22:49 UTC (see Fig. 3). Wind speeds are given as mean values over a 50-km-wide transect and retrieved with the PR models of Thompson et al. (using $\alpha=1.0$ ) and Mouche et al.

western half of Iceland. On the left panel, sea ice is clearly visible near the coast of Greenland. The right panel shows the coverage of the land and sea ice masks. The sea ice mask matches the visible ice-covered area well.

GMFs used for SAR wind retrieval are developed for data products acquired in C-band VV. A PR can be applied to adjust for the lower radar backscatter at $\mathrm{HH}$ polarization. Multiple formulations of the polarization exist (see the overviews by [39] and [40]). Most fall into one of two categories: 1) PRs with incidence angle dependence only and 2) PRs with incidence and azimuth angle dependence. Previous studies (e.g., [32]) indicate that the PR may also depend on the satellite sensor and calibration.

In this study, two PRs are tested on a limited set of satellite scenes prior to the wind retrieval processing for the entire data set over Iceland. The objective is to show the consequence of choosing one PR over another, more than it is to validate individual PR formulations (as offshore in situ data are not available). A subset of the Envisat ASAR scenes is processed with the formulation given originally by [41]. This model depends on the radar incidence angle and a constant called alpha. Here, the value of $\alpha$ is set to 1.0 , since the original value of 0.6 is known to overestimate winds from Envisat significantly [39], [40]. The same data subset is processed with the PR model 1, developed by [39], which takes the azimuth angle into account. Collocated SAR and atmospheric model data at some distance from the coast (in open ocean) where the GMF performs at its best are selected.

\section{B. HARMONIE Model}

Additional data for the period from September 2009 to present were obtained from reanalysis project using the mesoscale model HARMONIE, version 37h1.2 [24], [25].

The model domain, with 300-by-240 horizontal grid points, and a horizontal grid-point spacing of $2.5 \mathrm{~km}$ in both directions,
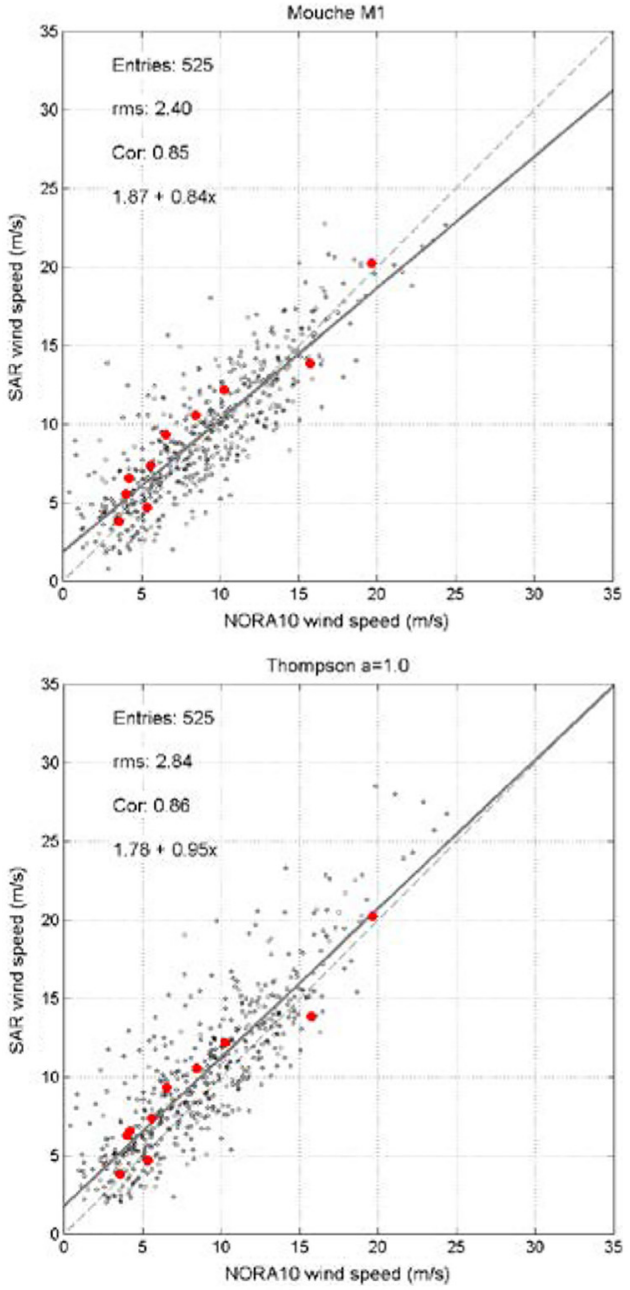

Fig. 5. Wind speed from NORA10 versus SAR, using the PRs of Mouche et al. and Thompson et al. The red dots are wind speed from VV. Linear correlation statistics are included.

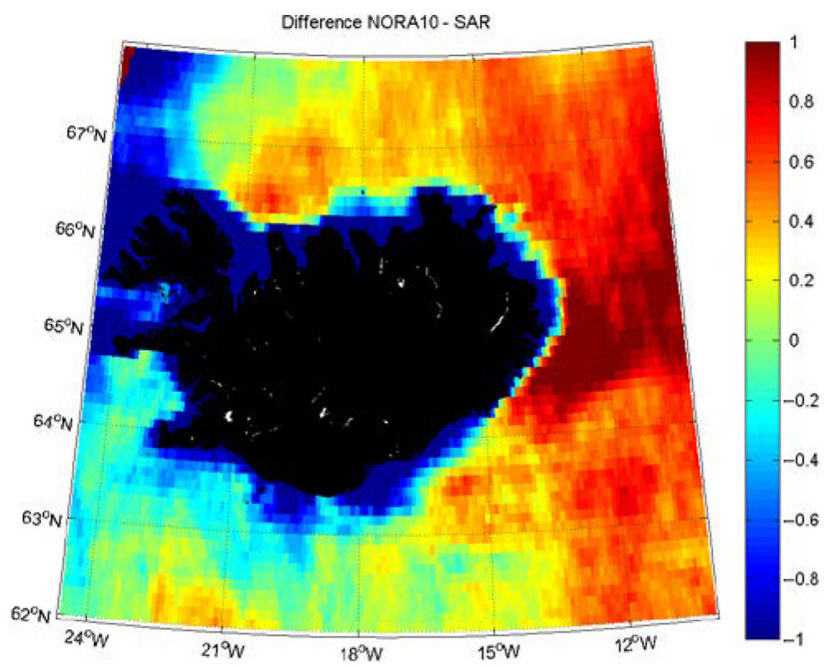

Fig. 6. Differences in mean wind speed $\left(\mathrm{ms}^{-1}\right)$ between NORA10 and SAR (NORA10 minus SAR).

encompasses Iceland and about $100 \mathrm{~km}$ of the surrounding ocean. The model was run with the standard 65 vertical levels, and with a nonhydrostatic dynamic core. Radiation, turbulence, 


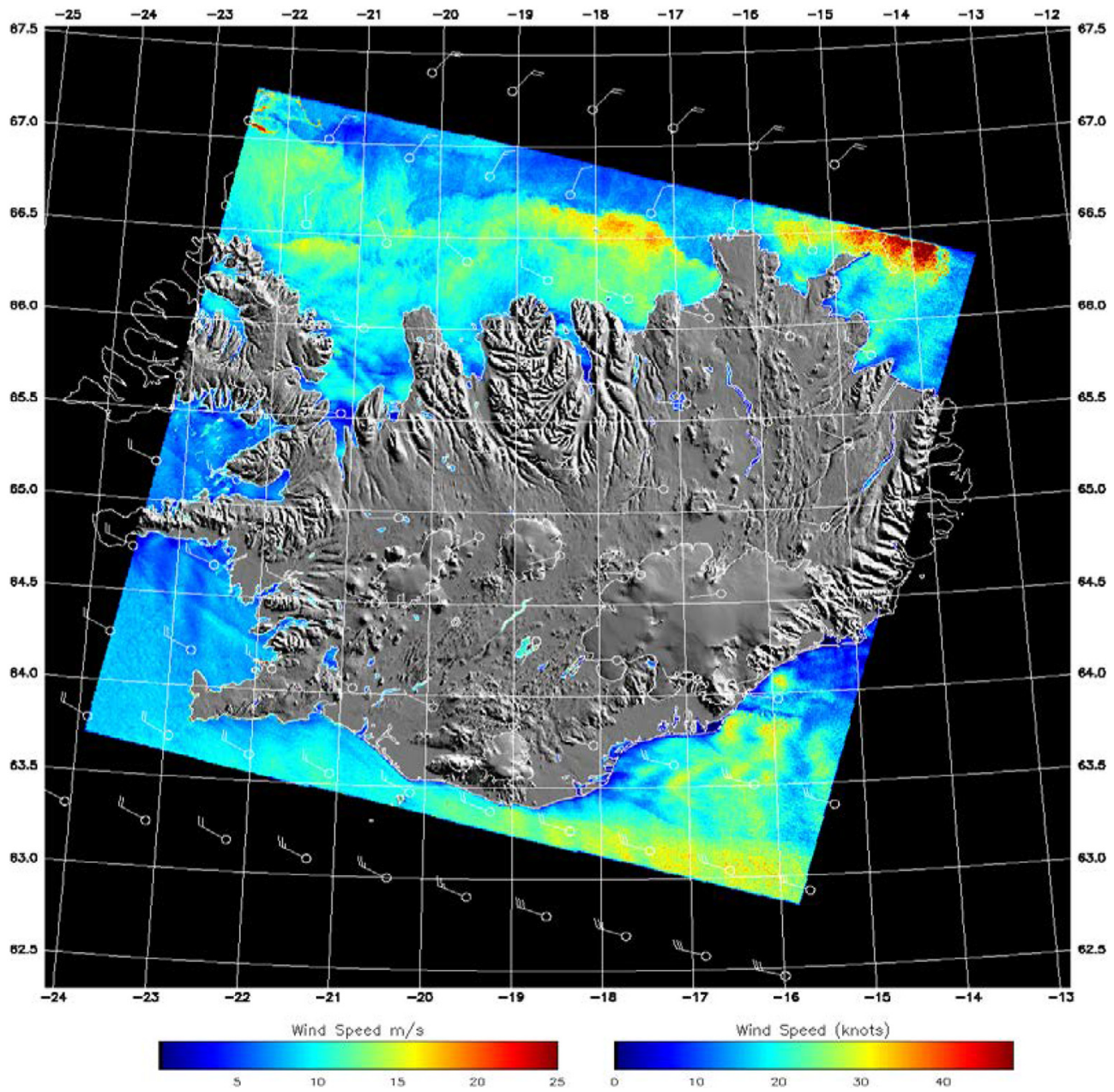

Fig. 7. Envisat ASAR wind field of Iceland, observed on 15 December 2005 at 11:35 UTC. The white barbs show the NOGAPS wind directions. The gray-scale shows elevation.

convection, and microphysics (clouds and precipitation) were determined by the AROME upper air physics scheme. Surface and soil processes were described by the external single-layer coupled surface scheme SURFEX. Initial and lateral boundary conditions were provided by European Centre for MediumRange Weather Forecasts (ECMWF) operational analyses. The model was run in upper air and surface data assimilation mode. The atmospheric analysis was handled such that initial and boundary conditions for each forecast run were combined with the output from the previous run (blending mode). Gridded surface analyses for 2-m air temperature and relative humidity, sea surface temperature, and snow water equivalent were prepared by the spatial interpolation tool CANARI.

\section{NORA10 Model}

The Norwegian Reanalysis of wind and waves (NORA10) is a downscaling of ECMWF global reanalysis ERA-40 [42] for the period 1957-2002 [26]. The downscaling is performed using the HIRLAM [43], with a 10-11-km horizontal grid-point spacing, covering the northern North Atlantic from south of Greenland to the Barents Sea and the North Sea in the east. Hourly surface winds from HIRLAM are used to run a wave model (WAM) on the same grid. From 2002 to present, the same model setup is used to downscale ECMWF forecasts. This is done to keep NORA10 updated. The model setup and downscaling procedure is described in detail by [26]. Verification of NORA10 winds is also provided therein, as well as by [27]. Note that Iceland is located close to the border of the NORA10 domain, which has an effect on the model winds in the northwest part of the area of interest.

\section{RESUlTS AND Discussion}

\section{A. Selection of $P R$}

The plot in Fig. 4 illustrates the difference in wind speed retrieved with the two PR models [39], [41] for a single image. The wind speed data are extracted across the entire Envisat swath with an incidence angle range of $16.6^{\circ}-42.7^{\circ}$. Winds are averaged over the 50-km-wide transect indicated in Fig. 3. At low incidence angles, the wind speeds retrieved with the polarization of Thompson et al. [41] with $\alpha$ set to 1.0 give much higher wind speeds than winds retrieved with the PR model of Mouche et al. [39]. The difference is more than 3 $\mathrm{ms}^{-1}$. The two plots approach the same value with increasing incidence angles. At $39^{\circ}$, the Mouche et al. model gives 
TABLE IV

KEy Findings IN Winds For CASES From ENVISAT ASAR AND HARMONIE MOdEL

\begin{tabular}{|c|c|c|}
\hline & Time & Key findings in wind fields SAR vs. HARMONIE \\
\hline A & $\begin{array}{l}10 \\
\text { Apr } \\
2010 \\
23: 09\end{array}$ & $\begin{array}{l}\text { Winds are from SW. Atmospheric divergent lee wake patterns east of Seley are } \\
\text { very pronounced both in model and SAR and they extent from the coastline } \\
\text { and more than } 100 \mathrm{~km} \text { towards the northeast. In the sea near Grímsey SAR } \\
\text { show higher wind speed gap flow than model but the lee effects are similar in } \\
\text { model and SAR. There is some discrepancy in wind directions. }\end{array}$ \\
\hline B & $\begin{array}{l}17 \\
\text { Oct } \\
2010 \\
22: 49\end{array}$ & $\begin{array}{l}\text { Winds are from the east. Coastal winds are weaker in the model, especially for } \\
\text { the gap flow in Faxaflói, the southwestern bay, in Breiðafjöður, and the middle } \\
\text { bay. The high winds in coastal barrier jet in the Denmark Strait near Iceland in } \\
\text { the north are much higher in SAR than in model. The overall spatial pattern is } \\
\text { similar between model and SAR. Model winds along the south coast compare } \\
\text { well to those in SAR and lower winds east of the Southern Peninsula are seen } \\
\text { both in model and SAR. Wind directions in wakes from SAR and model } \\
\text { compare well. }\end{array}$ \\
\hline $\mathrm{C}$ & $\begin{array}{l}10 \\
\text { Jan } \\
2011 \\
23: 09\end{array}$ & $\begin{array}{l}\text { Winds are from NE. The direction and extent of lee wakes west of Iceland are } \\
\text { similar in model and SAR but SAR shows much higher wind speed compared } \\
\text { to the model, in particular, in the Denmark Strait and higher gap flow in } \\
\text { Faxaflói and Breiðafjöður. }\end{array}$ \\
\hline $\mathrm{D}$ & $\begin{array}{l}18 \\
\operatorname{Mar} \\
2011 \\
22: 12\end{array}$ & $\begin{array}{l}\text { Winds are from W. The coastal lee wake off the east coast is captured well by } \\
\text { the model in the near-shore area compared to SAR. Wind directions are } \\
\text { similar. The wind pattern in the northeast in SAR show pronounced transverse } \\
\text { atmospheric gravity waves while the model show less variation. The model } \\
\text { shows clear atmospheric gravity waves from the south point of Vatnajökull and } \\
\text { along the coastline towards the west. Also SAR shows these gravity waves } \\
\text { whereas the wave pattern further offshore in SAR is not as regular as in the } \\
\text { model. }\end{array}$ \\
\hline $\mathrm{E}$ & $\begin{array}{l}24 \\
\text { May } \\
2011 \\
11: 30\end{array}$ & $\begin{array}{l}\text { Winds are from North. The pattern of wakes and northwesterly jets off the } \\
\text { southeast coast is captured well by the model. Model winds are somewhat } \\
\text { weaker. Wind directions are similar in SAR and model. It is clear that the SAR } \\
\text { shows more detail in the gap flows and greater flow concentration. }\end{array}$ \\
\hline $\mathrm{F}$ & $\begin{array}{l}10 \\
\text { Sep } \\
2011 \\
23: 02\end{array}$ & $\begin{array}{l}\text { Winds are from NE. Coastal lee wakes and gap flow west of Iceland from } \\
\text { model and SAR are very similar in wind direction, wind speed and spatial } \\
\text { pattern. The sharp gradient in wind speed south of Iceland is captured well } \\
\text { both in model and SAR though with SAR the features are even more } \\
\text { pronounced. In Breiðafjöður transverse lee wake pattern is seen in SAR. }\end{array}$ \\
\hline
\end{tabular}

higher wind speeds in agreement with previous findings of Mouche et al. [39].

Comparison of colocated ocean winds from SAR and NORA10 allows the data representation, open-ocean GMF, and PR to be tested. NORA10 and SAR winds are gridded to the same regular latitude-longitude grid over Iceland, covering $62-67.9^{\circ} \mathrm{N}$ and $24.6-10^{\circ} \mathrm{W}$ with a grid cell spacing of $0.1^{\circ}$. For a location in the open ocean north of Iceland (at 66.9N, 20.7W) with 525 collocated samples, results are shown in Fig. 5 for the two PRs. The linear correlation results have a slightly lower RMSE for Mouche et al. than for Thompson et al. We therefore choose to use Mouche et al. for this study.

Fig. 6 shows the difference between the NORA10 January 2005 and January 2012 mean wind speed and the SAR mean wind speed retrieved with the PR of Mouche et al. [39]. The upper left part in dark red (from $67^{\circ}-68^{\circ} \mathrm{N}$ to $22^{\circ}-24.5^{\circ} \mathrm{W}$ ) should not be considered due to border effects at the edge of the NORA10 model domain. Near the coast, NORA10 wind speed is probably too low due to topographic effects. The difference between the two maps shows the SAR mean wind speed to be $1 \mathrm{~ms}^{-1}$ higher near the coasts and in the northwest, while it is $0.5-1 \mathrm{~ms}^{-1}$ lower than NORA10 in the east.
The wind speed map in Fig. 7 is from 15 December 2005 at 11:35 UTC. It is $400 \mathrm{~km}$ wide, covering most of Iceland.

\section{B. Case Studies-SAR Versus HARMONIE}

Six case studies of wind conditions with significant coastal influence are examined (see Table IV). The cases are selected for different regions in Iceland. The wind field maps from SAR and HARMONIE are shown in Fig. 8. In the SAR images, the land is masked and digital elevation in gray-scale is shown. Cases B, C, and F are from the western part of Iceland, with prevailing atmospheric flow from the east and northeast. Common to all three cases are elongated streaks of elevated wind speeds through narrow fjords and over the larger bays between peninsulas, persisting for around $200 \mathrm{~km}$ downstream, separated by areas of lower wind speeds in the lee of coastal mountains. The wind directions from the NOGAPS and HARMONIE model compare well with the direction of the large-scale atmospheric flow features seen in SAR. Due to the higher spatial resolution, smaller scale features are visible in the SAR images more often than in the HARMONIE simulations. In general, the model 

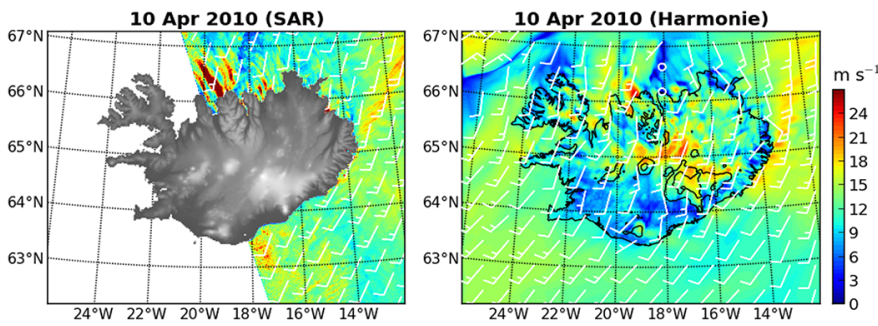

17 Oct 2010 (SAR)

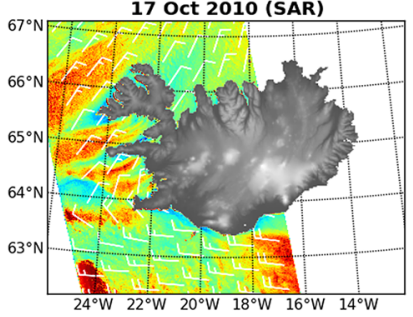

17 Oct 2010 (Harmonie)

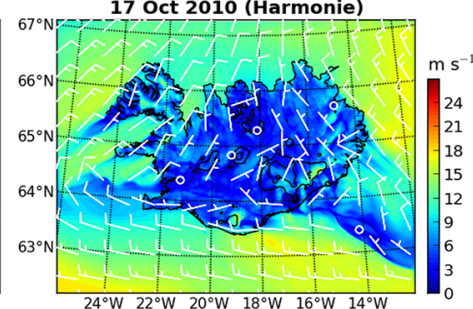

10 Jan 2011 (SAR)
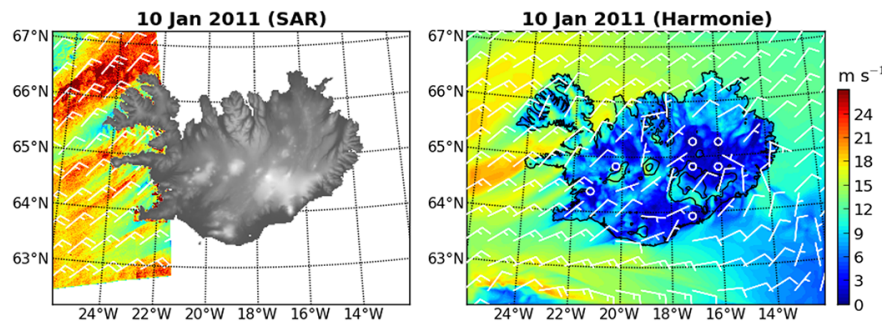

18 Mar 2011 (SAR)

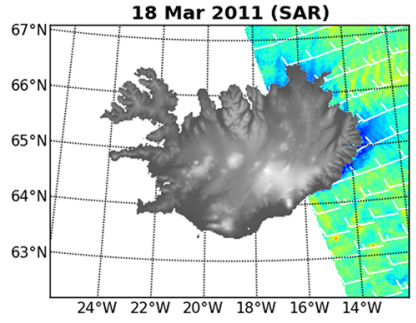

24 May 2011 (SAR)

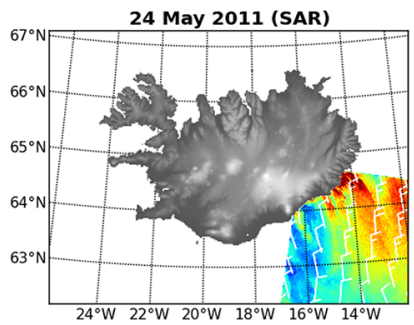

10 Sep 2011 (SAR)
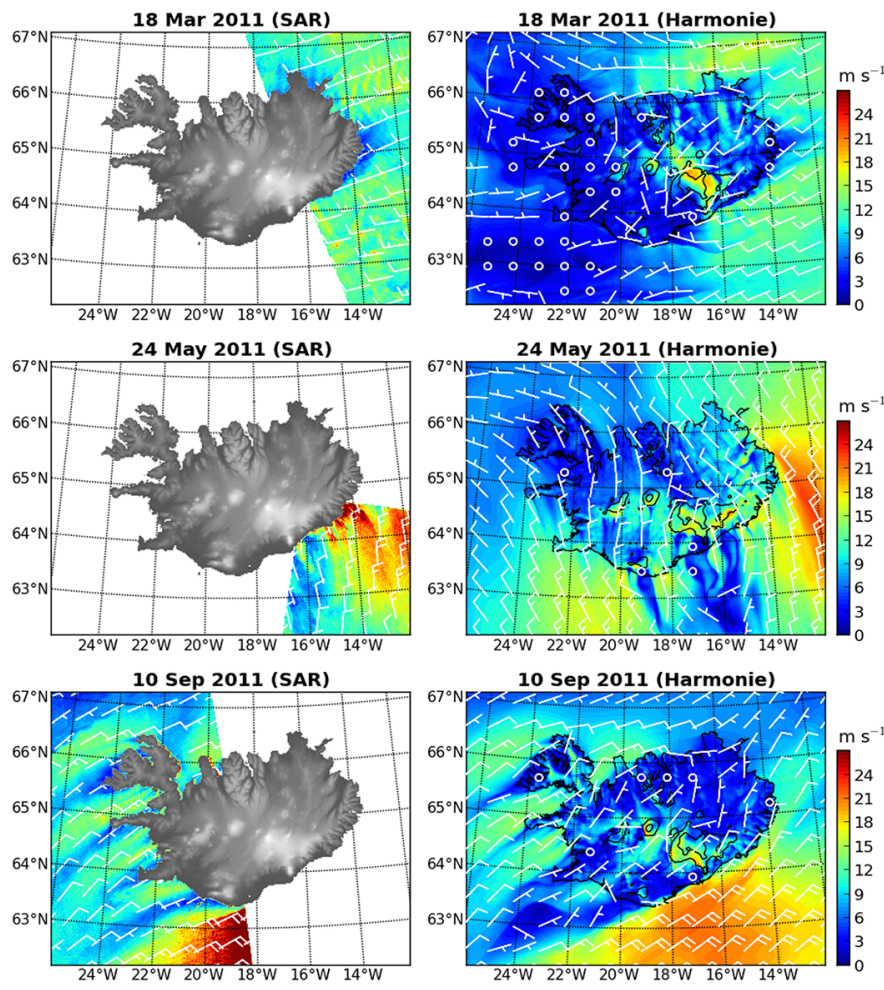

24 May 2011 (Harmonie)

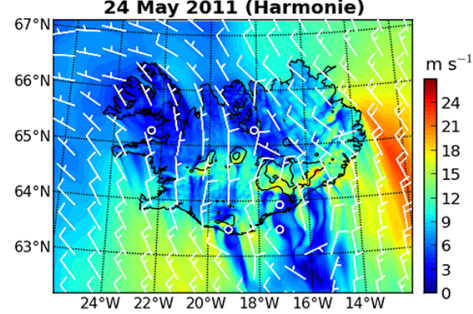

10 Sep 2011 (Harmonie)

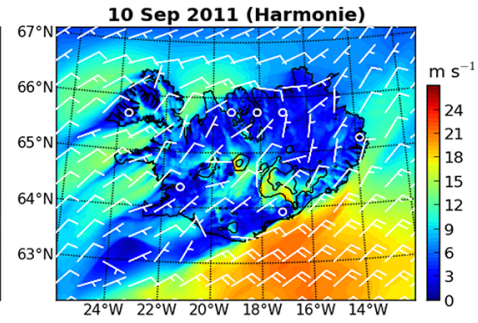

Fig. 8. Envisat ASAR wind speed maps with NOGAPS wind directions (left) and HARMONIE model results (right) for six cases with significant offshore coastal wind conditions in Iceland.

simulates lower background wind speeds than those observed by SAR. This is particularly noticeable for Cases B and C.

Cases A and D concern winds from the southwest and west, off the eastern part of Iceland. In both cases, lee-wake effects are seen. The winds are weaker and the extent of the lee effects is shorter than in Cases B and C. For Case A, the HARMONIE model captures well the overall wake features, particularly the band of high winds generated by the interactions of large-scale flow with the complex elevated terrain along the southeast coast of Iceland. The HARMONIE model wind speed is similar to the wind speed observed from SAR in both cases. For Case D, the wind directions from the HARMONIE and NOGAPS model compare well, and are parallel to the pattern of elevated wind speeds in the SAR data. Some discrepancy in wind directions can be seen in Case A, mainly north of Iceland.

To the south of Iceland, Case E shows the accelerating effects of gap flow emerging from the narrow fjords in SE-Iceland, and wake effects downstream of the glacier Vatnajökull in northerly winds. Wind directions from the two atmospheric models and the SAR wind features are similar. HARMONIE models the spatial variability of wind speed well, but has slightly lower absolute values than the SAR data. The influence of the orography extends around $200 \mathrm{~km}$ downstream of the coastline, and very sharp gradients in wind speed are observed near the coast.

\section{Wind Directions-SAR/NOGAPS versus Station Measurements}

In order to verify SAR/NOGAPS wind directions in coastal waters, NOGAPS data are compared to measurements from onshore coastal stations around Iceland. See Fig. 1 for the locations of these stations, and the grid points from which SAR/NOGAPS wind direction time series were obtained. For each time series, the occurrence of wind direction in $45^{\circ}$ sectors was determined (see Fig. 9). All wind direction histograms are normalized to $100 \%$. The minimum wind speed is $3 \mathrm{~m} \mathrm{~s}^{-1}$, which is a typical cut-in speed for large wind turbines.

As is well known, the coastal stations are significantly affected by the surrounding terrain, as well as by thermal land-sea gradients. The main problem, as far as a comparison of station and SAR/NOGAPS data is concerned, is the lack of spatial detail in NOGAPS. Since it is a global model, agreement on fine-scale wind features near the coast cannot be expected. On Seley, in the east [Fig. 9(d)], e.g., the dominant northerly winds modeled by NOGAPS are deflected toward the northeast. On Grímsey, in the north [Fig. 9(b)], the higher occurrence of southeasterly winds at the weather station, together with a reduced occurrence of northeasterly and easterly winds, is explainable by the slope of the local terrain, as the island slopes upward from west to east. At the western tip of Snæfellsnes, near Gufuskálar [Fig. 9(a)], the blocking effects from the volcano are clearly noticeable at the coast, with winds deflected either to easterly or southerly directions. These effects are absent in the wind directions from NOGAPS at the SAR reference location. However, from other directions, the wind roses are very similar. In the southwest [Fig. 9(c)], near Garðskagaviti, the similarity between the wind direction distributions is excellent. Near Heimaey (Vestmannaeyjar), the two data sets agree about the dominant wind directions from east and southeast. However, at the nearby SAR location, the offshore wind direction distribution is more uniform than on the island. The same is true near Eyrarbakki, where the prevailing northeasterly offshore winds, affected strongly by land-sea 


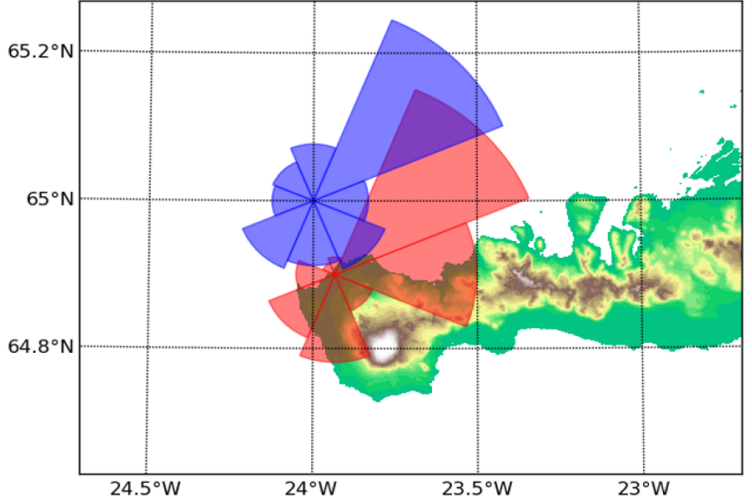

(a)

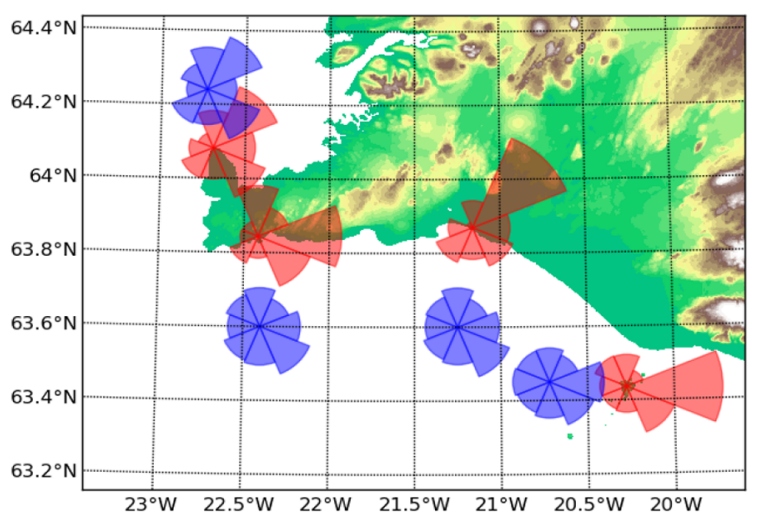

(c)

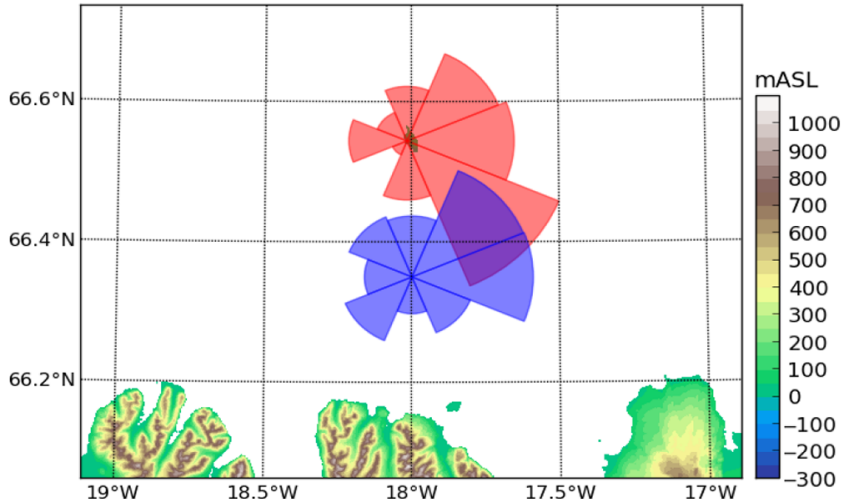

(b)

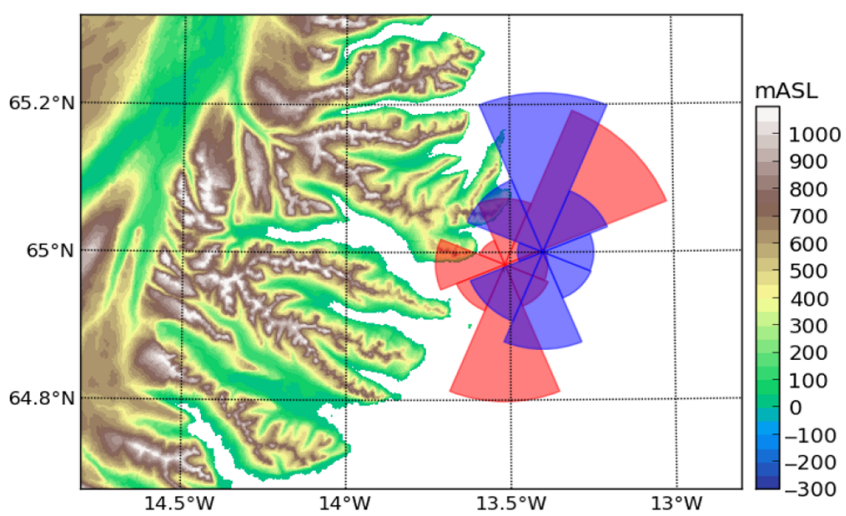

(d)

Fig. 9. Comparison of wind roses at the coastal stations (red) and offshore (blue) at the SAR reference points for: (a) Snæfellsnes, near Gufuskálar; (b) Grímsey; (c) Southwest Iceland including Heimaey (Vestmannaeyjarbær), Eyrarbakki, Grindavík and Garð̋skagaviti; (d) Seley.

temperature gradients, are not found at the nearest offshore SAR location.

\section{Wind Resource}

Mean annual wind speed, Weibull scale (A) and shape parameters $(\mathrm{k})$, and mean annual energy density at $10 \mathrm{~m}$ above sea level were calculated using the Satellite-WAsP (S-WAsP) [21]. The results are shown in Fig. 10. The mean wind speed ranges from 5 to $10 \mathrm{~ms}^{-1}$. Spatial patterns in the coastal wind field, seen for individual cases in Fig. 8, are also noticeable in the field of mean wind speed. The gap winds in the eastern fjords, the very strong winds in the Denmark Strait, and the lee wakes in Faxaflói and Breiðafjöður in the west are well-defined persistent features. Strong winds also occur along the southwestern coastline, while further east, lee effects are observed near the coast.

The map of Weibull scale parameter A shows similar spatial features as the mean wind speed, though with slightly higher values. The map of Weibull shape parameter $\mathrm{k}$ shows relatively low values around 1.5 at the northern and eastern coastline, while $\mathrm{k}$ is around a more typical value of 2 along the southern and western coastlines. The Weibull shape parameter of value 1.5 indicates a wind climate with large variability in winds (flat distribution), whereas the Weibull shape parameter of value 2 indicates a wind climate with more steady winds (peaked distribution). Average energy density is between 700 and $1000 \mathrm{Wm}^{-2}$ along the east and southwest coast. However, the highest values in these regions are found very close to the coast, and may be artifacts of image processing. The lowest values of $500-700 \mathrm{Wm}^{-2}$ occur along the north and southeast coast. Along most of the western coastline, the energy density is low as well, with the exception of most of the Westfjords. There, the highest values of $1400 \mathrm{Wm}^{-2}$ very close to the land are most likely also artifacts of image processing. The wind power is proportional to the cube of the wind speed, so error in SAR or model data will result in high error on wind power.

The high SAR wind speeds in the Denmark Strait may be affected by ocean currents. However, this region is not likely to be a choice for wind energy utilization, and will not be considered here.

For comparison, mean annual wind speed and power density, as well as the annual values of Weibull scale and shape parameters, were calculated based on HARMONIE reanalysis data (see Fig. 11). Neither the coverage during the day nor the time periods are the same for the SAR measurements and the HARMONIE reanalyses. However, the values in the coastal zone around Iceland are very similar for the two data sets. As for the SAR data, the lowest HARMONIE wind speeds of around 5-7 ms ${ }^{-1}$ occur along the north and southeast coast, and the highest wind speeds of around $10 \mathrm{~ms}^{-1}$ are found at the exposed tips of peninsulas in the west. The Weibull scale parameter also has a similar pattern as the average wind speed, but equally with slightly higher values. As for the SAR data, low values of power density of $500 \mathrm{Wm}^{-2}$ occur along the north and southeast coast. However, the high SAR values of 

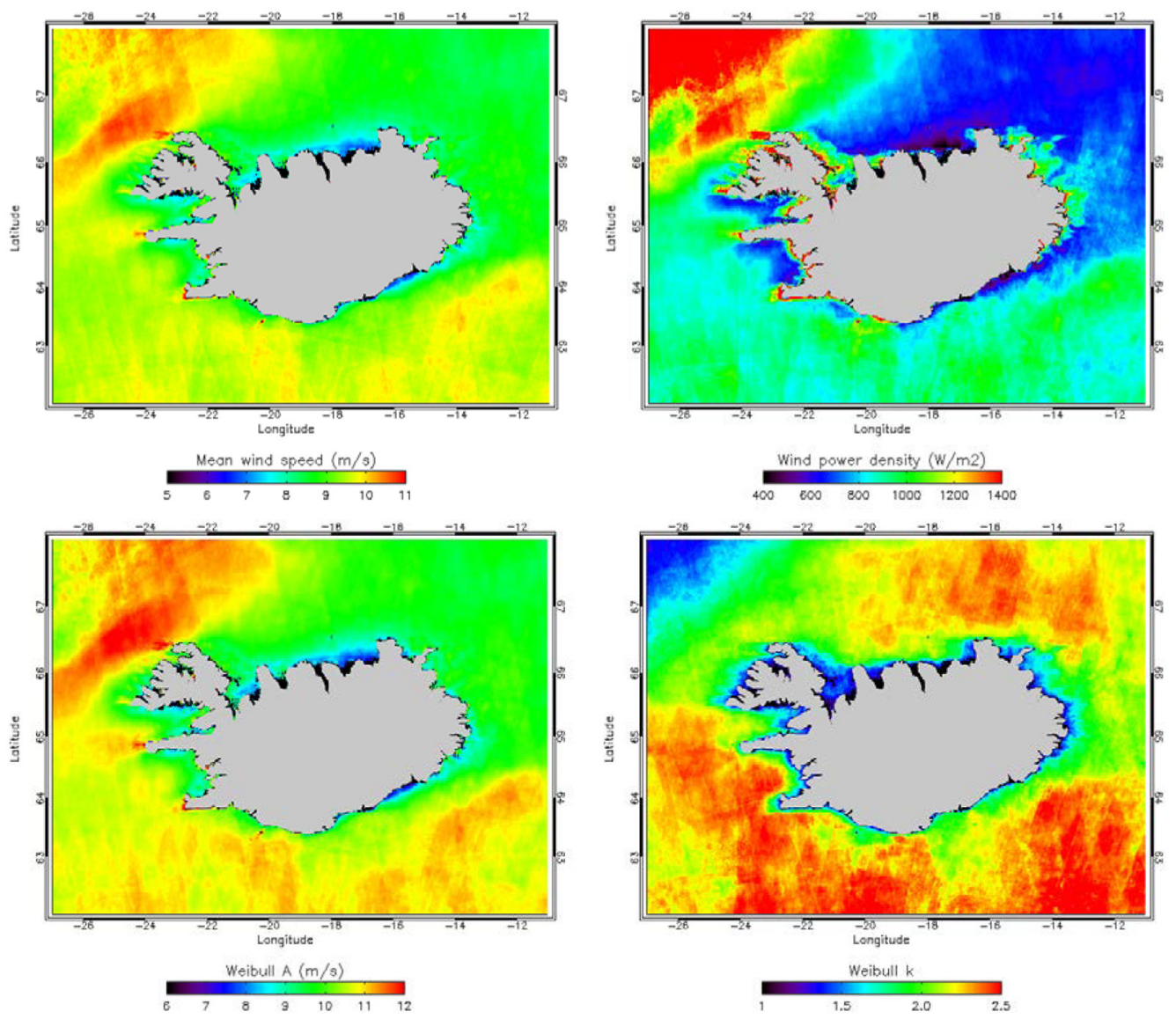

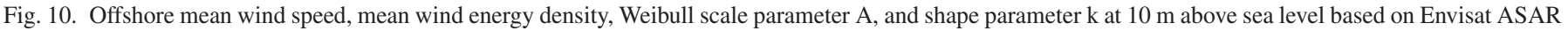
wind fields, for the period 2005-2012, and including hours 11-13 and 20-00 UTC.

$1000 \mathrm{Wm}^{-2}$ close to the east and southwest coast are not found in the model, suggesting again that they might be artifacts or SAR can resolve features smaller than the model. Based on HARMONIE data, the Weibull shape parameter is close to 2 along most of the Icelandic coastline. As for the SAR data, the lowest values exist off the northeast coast of the Westfjords. However, overall, the SAR-derived values are lower along the north and east coast, indicating that temporal variability of wind speed based on the satellite measurements is higher than in the mesoscale model.

\section{E. Discussion}

When satellite wind fields are used for offshore wind resource estimation in a new geographical area, it is advisable to critically investigate a set of issues. The first issue is the satellite wind field processing accuracy. The second issue is the spatial variability of observed winds. The third issue is the statistical representation of satellite wind field maps, including temporal variability.

Satellite SAR is expected to be useful for offshore wind resource estimation, with the capability to quantify coastal wind phenomena around Iceland at finer scales than through numerical modeling. The lack of offshore meteorological observations resulted in the following choices for the investigation of the satellite SAR wind fields.

The choice of GMF is CMOD5.N, one of the most recent models, and valid up to hurricane strength winds. The Envisat
ASAR archive for Iceland is dominated by $\mathrm{HH}$ polarization scenes, and the selection of PR is thus important. We use NORA10, collocated to SAR, to select the PR. The statistics between the tested PRs were not very different though. Further investigation to assess the consequences of the choice of PR for the mean wind speed map could be done. Testing of NOGAPS wind directions was performed by comparing wind roses observed at coastal weather stations in Iceland and nearby SAR/NOGAPS wind roses. The local effects of rugged terrain influence the coastal wind roses considerably, while the resolution of NOGAPS does not provide fine-scale detail. However, the agreement among most sites is good. The discrepancy in mean speed for collocated SAR and NORA10 samples is unexplained for the region east of Iceland, where NORA10 shows $0.5-1.0 \mathrm{~ms}^{-1}$ higher values than SAR. In most other areas, the discrepancy is lower. The underestimation of winds from NORA10 near coastlines and in the northwest area is explained by the model resolution and domain setup, respectively. It is clear that further investigation of PR, GMF, and wind direction near Iceland would be useful, in particular, if in situ observations become available, but even then it would be difficult to separate these effects. The recent work of [40] could be an option for improvement on PR.

The spatial variability of SAR wind speeds is investigated for six selected cases, using HARMONIE for comparison. Enhanced gap flow and lee-wake effects occur for all offshore wind directions around Iceland. For most cases, the wind directions between the HARMONIE and NOGAPS models agree 

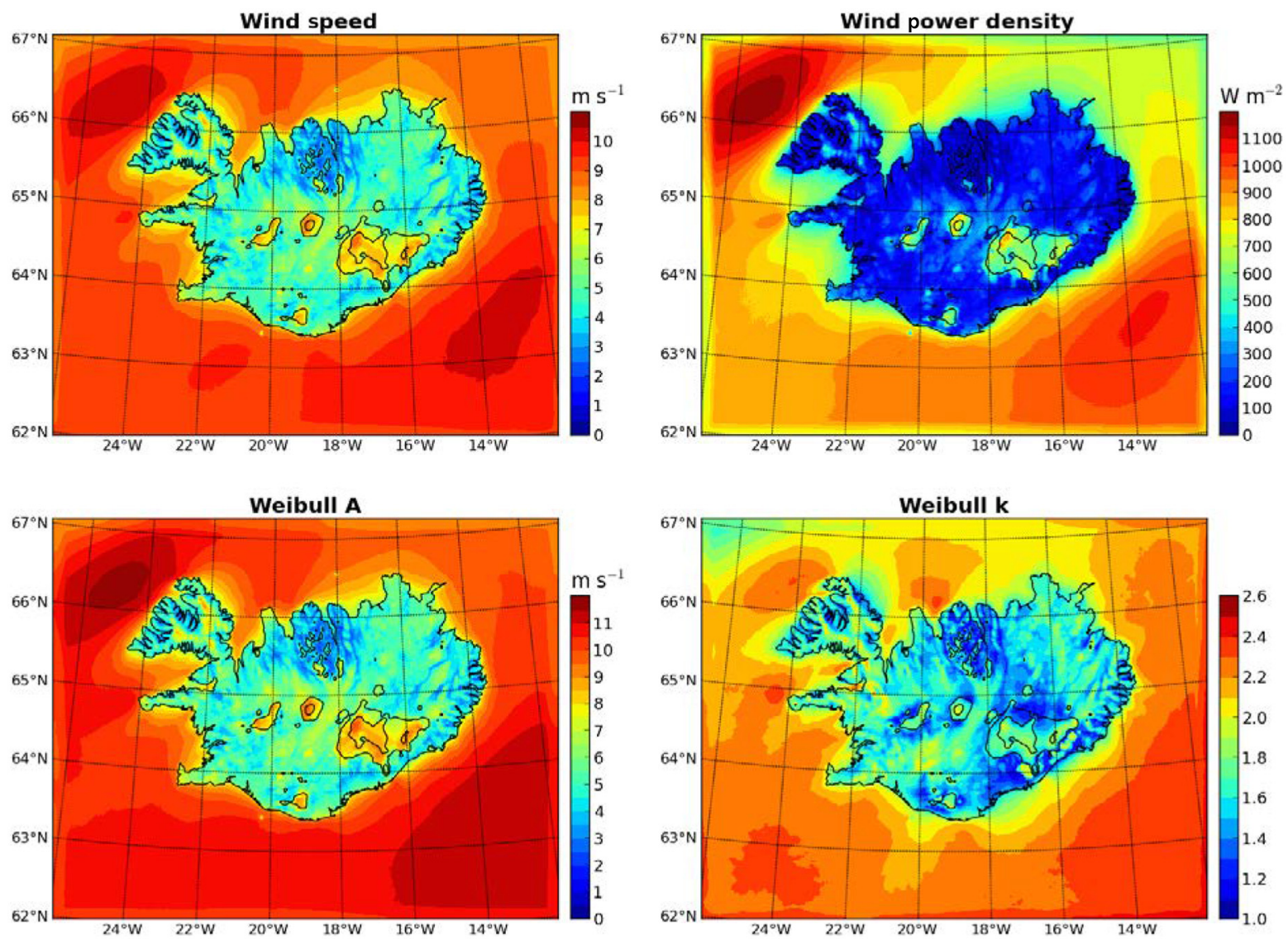

Fig. 11. Mean wind speed, mean wind energy density, Weibull scale parameter A, and shape parameter $\mathrm{k}$ at $10 \mathrm{~m}$ above sea level based on HARMONIE reanalysis data, for the period 2010-2012, and including all hours.

well. All reported cases have medium-to-high winds (around 6-20 ms ${ }^{-1}$ ). For very low wind speeds (less than $3 \mathrm{~ms}^{-1}$ ), wind directions are more variable and have relative higher uncertainty. The SAR-derived wind maps at $1 \times 1 \mathrm{~km}$ resolution have much spatial detail. According to [44], the spectral density in Envisat ASAR WSM wind maps is high. Thus, SAR wind fields observe small-scale variability of ocean surface winds. The smallest of these scales would not be modeled by HARMONIE, but the overall agreement between SAR and HARMONIE is good. Sharp gradients in wind speed are seen in Cases B, C, and F. It is interesting to notice the presence of atmospheric gravity waves both in SAR and HARMONIE. These, among other coastal wind phenomena, such as barrier jets, are also discussed in [28], [29], and [45]. The good agreement between SAR and HARMONIE model, regarding the representation of significant spatial patterns in coastal winds around Iceland, supports the combined use of SAR-derived wind maps and mesoscale model simulations for wind resource estimations.

The third issue to investigate is the statistical representation of satellite wind field maps, including temporal variability of the data set for wind resource statistics. The number of overlapping SAR wind maps near the coast of Iceland is more than 400 , which is expected to be sufficient for prefeasibility wind resource estimation [46]. The representation of seasonal variability in winds seems to be reasonably well captured in the present data set with monthly numbers of samples of around $200( \pm 50)$. The diurnal sampling is dictated by the satellite orbit, and SAR winds are observed only during two 3-h periods around noon and late evening. However, as shown in the Section III-E in comparison with the HARMONIE results, the SAR-derived wind field represents well the annual wind conditions.

The most promising coastal regions for wind energy production are along the southwestern coastline, with a mean annual energy density of around $700-1000 \mathrm{Wm}^{-2}$, and with values of the Weibull shape parameter $\mathrm{k}$ around 2. Along the northern coast, the energy density in several areas is above $1200 \mathrm{Wm}^{-2}$. However, this may be an artifact, due to sea ice not being fully avoided, despite the sea ice mask being applied. Areas with sea ice tend to give overestimated wind speed. This is also true around small peninsulas and islands, which are assumed to be water, but in reality are hard targets.

\section{CONCLUSION}

The wind resource results from satellite SAR, combined with HARMONIE model simulations, are useful for prefeasibility studies of the offshore wind energy resource around Iceland, i.e., early planning at a strategic level, while further investigation is needed for siting and development of wind farms.

The satellite SAR data indicate a high wind energy resource above $1000 \mathrm{Wm}^{-2}$ along the southwest coast, with slightly lower values based on model simulations. These results need further validation from on-site measurements, in case siting and 
development of wind farms is to take place. The limitations in the current assessment of winds from SAR around Iceland are that the selected GMF, PR, and wind direction input could not be verified with direct offshore observations.

Several specific atmospheric phenomena are captured well by both SAR and HARMONIE, with greater detail based on the satellite measurements. However, despite the lower resolution, the mesoscale model also has certain advantages. (a) Results are not affected by the presence of sea ice. (b) Data are regular (unbiased) in space and time. (c) Data are available at higher levels above the sea surface. (d) Wind direction is spatially colocated with wind speed, with a higher resolution than that from NOGAPS. A combination of the two data sources therefore gives the best results.

\section{REFERENCES}

[1] B. J. Hoskins and K. I. Hodges, "New perspectives on the Northern Hemisphere winter storm tracks,' J. Atmos. Sci., vol. 59, pp. 1041-1061, 2002.

[2] H. Ólafsson and H. Ágústsson, "The Freysnes downslope windstorm," Meteorol. Z., vol. 16, no. 1, pp. 123-130, 2007.

[3] H. Ágústsson and H. Ólafsson, "The bimodal downslope windstorms at Kvísker," Meteorol. Atmos. Phys., vol. 116, no. 1-2, pp. 27-42, 2010.

[4] H. Ágústsson and H. Ólafsson, "Simulating a severe windstorm in complex terrain," Meteorol. Z., vol. 16, no. 1, pp. 111-122, 2007.

[5] N. Nawri et al., "The wind energy potential of Iceland," Renew. Energy, vol. 69C, pp. 290-299, 2014.

[6] A. M. Sempreviva, R. B. Barthelmie, and S. C. Pryor, "Review of methodologies for offshore wind resource assessment in European Seas," Surveys Geophys., vol. 29, no. 6, pp. 471-497, 2008.

[7] A. N. Hahmann, C. L. Vincent, A. Peña, J. Lange, and C. B. Hasager, "Wind climate estimation using WRF model output: Method and model sensitivities over the sea," Int. J. Climatol., 2014, doi: 10.1002/joc.4217.

[8] B. R. Furevik, A. M. Sempreviva, L. Cavaleri, J.-M. Lefèvre, and C. Transerici, "Eight years of wind measurements from scatterometer for wind resource mapping in the Mediterranean Sea," Wind Energy, vol. 14, no. 3, pp. 355-372, 2011.

[9] I. Karagali, M. Badger, A. Hahmann, A. Peña, C. B. Hasager, and A. M. Sempreviva, "Spatial and temporal variability in winds in the Northern European Seas," Renew. Energy, vol. 57, pp. 200-210, 2013.

[10] I. Karagali, A. Peña, M. Badger, and C. B. Hasager, "Wind characteristics in the North and Baltic Seas from the QuikSCAT satellite," Wind Energy, vol. 17, no. 1, pp. 123-140, 2014.

[11] K.-F. Dagestad et al., "Wind retrieval from synthetic aperture radar - An overview," in Proc. 4th SAR Oceanogr. Workshop (SEASAR'12), Troms $\emptyset$, Norway, Jun. 18-22, 2013, pp. 1-22.

[12] C. B. Hasager et al., "Remote sensing observation used in offshore wind energy," IEEE J. Sel. Topics Appl. Earth Observ. Remote Sens., vol. 1, no. 1, pp. 67-79, Mar. 2008.

[13] M. B. Christiansen, W. Koch, J. Horstmann, C. B. Hasager, and M. Nielsen, "Wind resource assessment from C-band SAR," Remote Sens. Environ., vol. 105, pp. 68-81, 2006.

[14] R. J. Barthelmie, J. Badger, S. C. Pryor, C. B. Hasager, M. B. Christiansen, and B. H. Jørgensen, "Offshore coastal wind speed gradients: Issues for the design and development of large offshore wind farms," Wind Eng., vol. 31, no. 6, pp. 369-382, 2007.

[15] C. B. Hasager et al., "Offshore wind resource estimation from satellite SAR wind field maps," Wind Energy, vol. 8, pp. 403-419, 2005.

[16] J. Choisnard, G. Lafrance, and M. Bernier, "SAR-satellite for offshore and coastal wind resource analysis, with examples from St. Lawrence Gulf, Canada," Wind Eng., vol. 28, pp. 367-382, 2004.

[17] P. Beaucage, M. Bernier, G. Lafrance, and J. Choisnard, "Regional mapping of the offshore wind resource: Towards a significant contribution from space-borne synthetic aperture radars," IEEE J. Sel. Topics Appl. Earth Observ. Remote Sens., vol. 1, no. 1, pp. 48-56, Mar. 2008.

[18] Y. Takeyama, T. Ohsawa, K. Kozai, C. B. Hasager, and M. Badger, "Effectiveness of WRF wind direction for retrieving coastal sea surface wind from synthetic aperture radar," Wind Energy, vol. 16, pp. 865-878, 2013.

[19] R. Chang et al., "Applicability of synthetic aperture radar wind retrievals on offshore wind resources assessment in Hangzhou Bay, China," Energies, vol. 7, pp. 3339-3354, 2014.
[20] R. Chang et al., "Offshore wind resources assessment from multiple satellite data and WRF modeling over South China Sea," Remote Sens., vol. 7, pp. 467-487, 2015.

[21] C. B. Hasager et al., "Offshore wind climatology based on synergetic use of Envisat ASAR, ASCAT and QuikSCAT," Remote Sens. Environ., vol. 156, pp. 247-263, 2015.

[22] R. J. Barthelmie and S. C. Pryor, "Can satellite sampling of offshore wind speeds realistically represent wind speed distributions," J. Appl. Meteorol., vol. 42, no. 1, pp. 83-94, 2003.

[23] S. C. Pryor, M. Nielsen, R. J. Barthelmie, and J. Mann, "Can satellite sampling of offshore wind speeds realistically represent wind speed distributions? Part II Quantifying uncertainties associated with sampling strategy and distribution fitting methods," J. Appl. Meteorol., vol. 43, pp. 739-750, 2004.

[24] P. Brousseau, L. Berre, F. Bouttier, and G. Desroziers, "Background-error covariances for a convective-scale data-assimilation system: AROME France 3D-Var," Quart. J. Roy. Meteorol. Soc., vol. 137, pp. 409-422, 2011.

[25] Y. Seity et al., "The AROME - France convective-scale operational model," Mon. Weather. Rev., vol. 139, pp. 976-991, 2011.

[26] M. Reistad, Ø. Breivik, H. Haakenstad, O. J. Aarnes, B. R. Furevik, and J.-R. Bidlot, "A high-resolution hindcast of wind and waves for The North Sea, the Norwegian Sea and the Barents Sea," J. Geophys. Res., vol. 116, no. C05019, 18 p., 2011, doi: 10.1029/2010JC006402.

[27] B. R. Furevik and H. Haakenstad, "Near-surface marine wind profiles from rawinsonde and NORA10 hindcast," J. Geophys. Res. Atmos., vol. 117, no. D23106, pp. 1-14, 2012.

[28] R. C. Beal, G. S. Young, F. M. Monaldo, D. R. Thompson, N. S. Winstead, and C. A. Scott, High Resolution Wind Monitoring with Wide Swath SAR: A User's Guide. Washington, DC, USA: U.S. Department of Commerce, National Oceanic and Atmospheric Administration, National Environmental Satellite, Data, and Information Service, Office of Research and Applications, 2005, pp. 1-155.

[29] N. S. Winstead et al., "Using SAR remote sensing, field observations, and models to better understand coastal flows in the Gulf of Alaska," Bull. Amer. Meteorol. Soc., vol. 87, pp. 787-800, 2006.

[30] B. Furevik, O. Johannessen, and A. D. Sandvik, "SAR-retrieved wind in polar regions - Comparison with in situ data and atmospheric model output," IEEE Trans. Geosci. Remote Sens., vol. 40, no. 8, pp. 1720-1732, Aug. 2002.

[31] A. D. Sandvik and B. R. Furevik, "Case study of a coastal jet at Spitsbergen - Comparison of SAR and model estimated wind," Mon. Weather Rev., vol. 19, pp. 1040-1051, 2002.

[32] J. Horstmann, W. Koch, S. Lehner, and R. Tonboe, "Ocean winds from RADARSAT-1 ScanSAR,” Can. J. Remote Sens., vol. 28, no. 3, pp. 524533, 2002

[33] M. M. Gierach, H. C. Graber, and M. J. Caruso, "SAR-derived gap jet characteristics in the lee of the Philippine Archipelago," J. Remote Sens. Environ., vol. 117, pp. 289-300, 2012.

[34] C. B. Hasager, M. Badger, A. Peña, and X. G. Larsén, "SAR-based wind resource statistics in the Baltic Sea," Remote Sens., vol. 3, no. 1, pp. 117144, 2011.

[35] T. F. Hogan and T. E. Rosmond, "The description of the navy operational global atmospheric prediction system's spectral forecast model," Mon. Weather Rev., vol. 119, pp. 1786-1815, 1991.

[36] J. Karvonen, "Baltic Sea ice concentration estimation based on C-band HH-polarized SAR data," IEEE J. Sel. Topics Appl. Earth Observ. Remote Sens., vol. 5, no. 6, pp. 1874-1884, Dec. 2012.

[37] H. Hersbach, "Comparison of C-band scatterometer CMOD5N equivalent neutral winds with ECMWF," J. Atmos. Ocean. Technol., vol. 27, pp. 721-736, 2010.

[38] F. M. Monaldo, D. R. Thompson, W. G. Pichel, and P. Clemente-Colon, "A systematic comparison of QuikSCAT and SAR ocean surface wind speeds," IEEE Trans. Geosci. Remote Sens., vol. 42, no. 2, pp. 283-291, Feb. 2004.

[39] A. Mouche, D. Hauser, J.-F. Daloze, and C. Guerin, "Dual-polarization measurements at C-band over the ocean: Results from airborne radar observations and comparison with Envisat ASAR data," IEEE Trans. Geosci. Remote Sens., vol. 43, no. 4, pp. 753-769, Apr. 2005.

[40] G. Liu et al., "A systematic comparison of the effect of polarization ratio models on sea surface wind retrieval from C-band synthetic aperture radar," IEEE J. Sel. Topics Appl. Earth Observ. Remote Sens., vol. 6, no. 3, pp. 1100-1108, Jun. 2013.

[41] D. Thompson, T. Elfouhaily, and B. Chapron, "Polarization ratio for microwave backscattering from the ocean surface at low to moderate incidence angles," in Handbook of Wind Power Systems, P. Pardalos, S. Rebennack, M. V. F. Pereira, N. A. Iliadis and V. Pappu, Eds. Heidelberg, Berlin: Springer, 1998, pp. 1671-1676. 
[42] S. M. Uppala et al., "The ERA-40 re-analysis," Quat. J. Roy. Meteorol. Soc., vol. 131, pp. 2961-3012, 2005.

[43] P. Undén et al., "HIRLAM-5 scientific documentation," Swed. Meteorol. Hydrol. Inst., Norrköping, Sweden, 2002, pp. 1-144.

[44] I. Karagali, X. G. Larsén, M. Badger, A. Peña, and C. B. Hasager, "Spectral properties of ENVISAT ASAR and QuikSCAT surface winds in the North Sea," Remote Sens., vol. 5, no. 11, pp. 6096-6115, 2013.

[45] X. Li, "Atmospheric vortex streets and gravity waves," in Synthetic Aperture Radar Marine User's Manual, C. R. Jackson and J. R. Apel, Eds. Washington, DC, USA: National Oceanic and Atmospheric Administration (NOAA), National Environmental Satellite, Data, and Information Service (NESDIS), Office of Research and Applications, Washington D.C, 2004, pp. 341-354.

[46] M. Badger, J. Badger, M. Nielsen, C. B. Hasager, and A. Peña, "Wind class sampling of satellite SAR imagery for offshore wind resource mapping," J. Appl. Meteorol. Climatol., vol. 49, no. 12, pp. 2474-2491, 2010

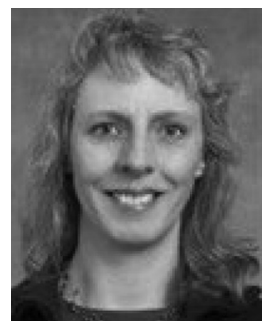

Charlotte Bay Hasager received the M.Sc. and $\mathrm{Ph} . \mathrm{D}$. degrees in geography from the University of Copenhagen, Copenhagen, Denmark, in 1992 and 1996, respectively

Currently, she is a Senior Scientist with DTU Wind Energy Department, Technical University of Denmark, Roskilde, Denmark. Since 2013, she has been a Leader with the Offshore Wind Power Meteorology Team. He has been the President of the Atmospheric Sciences Division, European Geosciences Union, Munich, Germany, from 2007 to 2011. Her research interests include offshore wind energy and using satellite and ground-based remote sensing for wind profiles, wind power meteorology, wind resources, turbulence, experimental field work and theoretical work on atmospheric boundary layer structure and dynamics over heterogeneous land, coastal regions, the sea, satellite remote sensing, micrometeorology, wind energy, boundary-layer meteorology, data analysis, statistics, and satellite remote-sensing image processing.

Dr. Hasager has been a Member of the Steering Committee of the Danish Space Consortium, from 2005 to 2010, the Co-Chair of the Wind Energy Community of Practise, GEOSS, from 2005 to present, an External Examiner with the University of Copenhagen and Roskilde University Center in Geography, from 1997 to present.

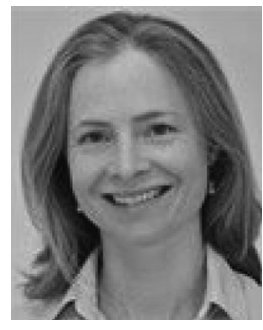

Merete Badger received the M.Sc. and Ph.D. degrees in geography from the University of Copenhagen, Copenhagen, Denmark, in 2002 and 2006, respectively.

Currently, she is a Senior Scientist with the Department of Wind Energy, Technical University of Denmark, Roskilde, Denmark. She is currently coordinating DTU Wind Energy's online teaching activities and responsible for other activities related to e-learning and e-infrastructure. Her research interests include wind retrieval from SAR and the application of SAR winds to offshore wind resource assessment, analyses of wind farm wake effects, validation of atmospheric models, satellite remote sensing, micrometeorology, and wind energy.

Dr. Badger has coordinated several international projects and is a Principal Investigator of multiple projects through the European Space Agency (ESA).

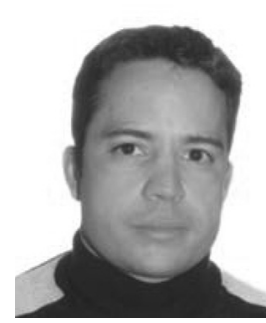

Nikolai Nawri received the M.Sc. and Ph.D. degrees in meteorology from the University of Maryland, MD, USA, in 2000 and 2003 , respectively.

From 2003 to 2008, he was a Postdoctoral Researcher with McGill University, Montréal, QC, Canada, organizing and participating in field work aimed at improving the understanding of highlatitude extreme weather. Currently, he is a Scientist with the Icelandic Meteorological Office, Reykjavik, Iceland, working on wind energy assessments for Iceland, as well as other topics, such as weather hazards, cyclones, and weather conditions associated with major avalanche cycles.

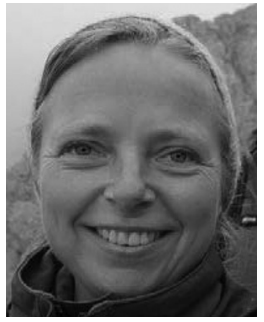

Birgitte Rugaard Furevik received the M.Sc. degree in oceanography from the University of Copenhagen, Copenhagen, Denmark, in 1995 and the Ph.D. degree in oceanography from the University of Bergen, Bergen, Norway, on the topic of wind retrieval from SAR and applications in the marginal ice zone and coastal regions.

From 2002 to 2004, she had a Postdoctorate position with Nansen Environmental and Remote Sensing Center, Bergen, Norway, where she worked with microwave remote sensing for offshore wind resource estimation. Since 2005, she has been working as a Research Scientist with Norwegian Meteorological Institute, Bergen, Norways, where she is responsible for coastal wave modeling and wave forecasting using the wave model SWAN. Her research interests include surface waves, the marine boundary layer and model verification, wind profiles, coastal variability, and mesoscale.

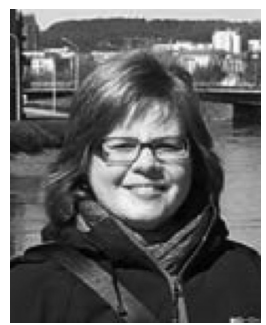

Guðrún Nína Petersen received the M.Sc. and Ph.D. degrees in meteorology from the University of Oslo, Oslo, Norway, in 1999 and 2004, respectively.

From 2004 to 2006, she was a Research Fellow with the University of Reading, Reading, U.K., and from 2006 to 2008, a Postdoctoral Researcher with the University of East Anglia, Norwich, U.K., organizing and participating in an airborne field campaign with emphasis on air-sea fluxes and orographic flow distortion. Currently, she is a Scientist with the Icelandic Meteorological Office, Reykjavik, Iceland. She has experience in numerical weather prediction, processing, and analyzing meteorological observations. Her research interests include high-latitude extreme weather and related fields such as air-sea interactions, high-latitude boundary layer meteorology, and the wind resource.

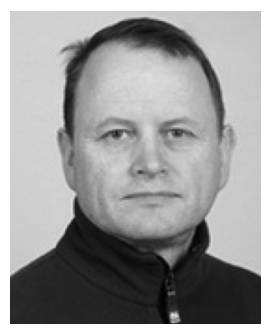

Halldór Björnsson received the Ph.D. degree in atmospheric and oceanic sciences from McGill University, Montreal, Quebec, Canada, in 1997.

$\mathrm{He}$ subsequently taught meteorology at the Department of Atmospheric and Oceanic Sciences, McGill University and did research on sea ice. From 1998 to 2000, he was a Postdoctoral Researcher in the Program of Atmosphere and Ocean Sciences with the Department of Geosciences, Princeton University. There, he worked at the Geophysical Fluid Dynamics Laboratory on ocean modeling, exploring the origin of the overall structure (thermal and salinity) of the world's oceans, and the influences this has on the global climate. In the fall of 2000, he started working with the Icelandic Meteorological Office and since 2004 has been the Head of research and development with the Weather Department. In 2007, he was appointed the Chair of a committee established by the Minister for the Environment to study the effects of climate change on nature and society in Iceland. His research interests include climate modeling, climate variability, and climate change

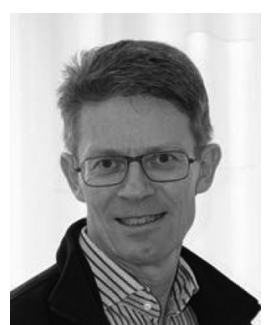

Niels-Erik Clausen received the M.Sc. and Ph.D. degrees in mechanical engineering from the Technical University of Denmark (DTU), Kongens Lyngby, Denmark, in 1980 and 1984, respectively.

$\mathrm{He}$ is an Associate Professor and Head of Study Board at DTU Wind Energy. Previously, he has worked with Risø National Laboratory for Sustainable Energy, Roskilde, Denmark, Burmeister \& Wain Scandinavian Contractor A/S, Allerød, Denmark, and Alfa-Laval Desalt (previously AtlasDanmark), Avedøre, Denmark. 